\title{
Recovery of Thalassiosira weissflogii from nitrogen and silicon starvation
}

\author{
Christina L. De La Rocha \\ University of Cambridge, Department of Earth Sciences, Downing Street, Cambridge CB2 3EQ, UK
}

Uta Passow

Alfred-Wegener-Institut für Polar und Meeresforschung, Bremerhaven, Germany

\begin{abstract}
The ecological success of marine diatoms comes despite their unusual additional requirement for silicon, a nutrient that often limits their growth in the ocean. There may be, however, some physiological and ecological advantages to silicon limitation. A model of nitrogen and silicon metabolism in diatoms (Flynn et al. 1997; Flynn and MartinJézéquel 2000) suggests that silicon-starved diatoms will recover more quickly than nitrogen-starved (but otherwise identical) diatoms on the resupply of nutrients. In culture, following $24 \mathrm{~h}$ of stationary phase induced by nutrient exhaustion, silicon-starved Thalassiosira weissflogii displayed maximum growth rates within a few hours of the readdition of silicon. But $37 \mathrm{~h}$ elapsed before nitrate-starved cultures began dividing again and nitrate-starved cultures did not reattain maximum growth rates over the period investigated. The model suggests that, in terms of number, cells descended from the nitrate starved will never catch up to cells descended from the silicon starved if both populations are simultaneously supplied with a pulse of nutrients. The longer the lag between nutrient supply and the resumption of growth in the nitrate-starved cells, the greater the proportion of the supplied nutrients that ends up in the descendants of the silicon starved. In the model run, the silicon-starved cells acquired $75 \%$ of the added nutrients and the nitrate starved acquired only 25\%. Silicon limitation may thus be a mechanism by which diatoms ensure they respond more quickly than other phytoplankton to the upwelling of nutrients into the euphotic zone.
\end{abstract}

Diatoms are astoundingly successful phytoplankton despite somewhat uniquely requiring silicon for growth in an ocean largely depleted of silicic acid. Silicon limitation of diatom growth in the ocean has been observed in locations ranging from high-nutrient, upwelling zones in the eastern equatorial Pacific (Dugdale et al. 1995) to the Mississippi River plume (Nelson and Dortch 1996) and the oligotrophic Sargasso Sea (Brzezinski and Nelson 1996). Despite this widespread potential for silicon limitation, diatoms manage to account for $75 \%$ of the primary production occurring in high-nutrient and coastal regions of the ocean and as much as $40 \%$ of the total annual marine primary production. Because marine primary production constitutes about half of the total of global primary production, marine diatoms carry out $20 \%$ of the primary production that occurs on Earth each year.

The success of diatoms is thus somewhat of a paradox. Further confounding the situation is their often inefficient use of and somewhat cavalier attitude toward silicic acid. Diatoms in low-nutrient areas display low affinities for silicic acid (Brzezinski and Nelson 1996), which at face value

\footnotetext{
${ }^{1}$ Corresponding author (christina00@esc.cam.ac.uk).
}

\section{Acknowledgments}

We thank Gerald Langer for all of his cheerful help and, along with Anja Engel, Kai Schulz, Markus Shartau, André Wischmeyer, Cristel Heemann, Irini Mataliotaki, Silke Thoms, Victor Smetacek, Richard Crawford, and Ulf Riebesell, for conversations and/or emergency supplies as the experiment progressed. This research was supported by the Alfred-Wegener-Institute. Additional thanks are owed to Dieter Wolf-Gladrow and the Carbon Group for encouraging and supporting the visit of C.L.D and to two anonymous reviewers whose comments greatly improved this manuscript. should diminish the diatoms' ability to compete for the also limited stocks of nitrogen, phosphorus, and trace metals by diminishing diatom growth rates relative to those of nonsiliceous phytoplankton. The actions of diatoms also work to excessively remove silicic acid from surface waters, which already hover around the 1:1 molar ratio of silicic acid and dissolved inorganic nitrogen (DIN) that is the boundary between silicon and nitrogen limitation (Brzezinski 1985; Levasseur and Therriault 1987). The refractory nature of biogenic opal relative to organic matter leads to the pumping of silicon to deeper depths than nitrogen during the export and remineralization of diatoms from the euphotic zone (Broecker and Peng 1982; Dugdale et al. 1995). And last, the continued uptake of silicic acid by Fe-limited diatoms (Takeda 1998; Hutchins and Bruland 1998; De La Rocha et al. 2000) pushes Fe-limited surface waters toward the depletion of silicon rather than nitrogen (e.g., Dugdale et al. 1995).

One answer to the paradox of diatom success would be for the siliceous frustule to be imparting a competitive advantage to the diatoms that makes up for the loss of productivity due to silicon limitation. Many useful qualities for silica have been proposed. For example, the use of silica in the cell wall requires an order of magnitude less energy than does the use of more typical materials such as lignin (Raven 1983). The silica frustule may account for up to $30 \%$ of the absorption of ultraviolet radiation by diatom cells (Davidson et al. 1994), reducing damage done to DNA and other vital components of the cell. The siliceous frustule may protect diatoms from grazers (Banse 1995) or viruses. Silica has also been proposed to aid in the acquisition of carbon for photosynthesis by serving as a buffer in the conversion of 
Table 1. Values of constants used in the model runs. Names of constants are as outlined in Flynn et al. (1997) and Flynn and Martin-Jézéquel (2000).

\begin{tabular}{|c|c|c|}
\hline Constant & Value & Unit \\
\hline AaskGln & 0.001 & $\mathrm{~N}: \mathrm{C}$ (mass) \\
\hline Cresk & 0.01 & \\
\hline CresQ & 0.2 & $\mathrm{~N}: \mathrm{C}$ (mass) \\
\hline GLNPm & 0.01 & $\mathrm{~N}: \mathrm{C}$ (mass) \\
\hline GShGLN & 0.01 & \\
\hline GsmNH4 & $1.75 \times 10^{-5}$ & $\mathrm{~N}: \mathrm{C}$ (mass) \\
\hline $\mathrm{Kq}$ & 0.02 & $\mathrm{~N}: \mathrm{C}$ (mass) \\
\hline NH4A & 0.05 & $\mathrm{~N}: \mathrm{C} / \mathrm{h}$ \\
\hline NH4GLN & 0.1 & \\
\hline NH4P & 0.1 & \\
\hline NH4kT & 0.014 & $\mu \mathrm{g} \mathrm{N} \mathrm{ml} l^{-1}$ \\
\hline NH4mGLN & 0.01 & $\mathrm{~N}: \mathrm{C}$ (mass) \\
\hline NH4Pm & 0.002 & $\mathrm{~N}: \mathrm{C}$ (mass) \\
\hline NO3A & -0.075 & \\
\hline NO3B & 0.2 & \\
\hline $\mathrm{NO} 3 \mathrm{C}$ & -0.4 & \\
\hline NO3hGLN & 0.005 & \\
\hline NO3hP & 0.05 & \\
\hline NO3kT & 0.014 & $\mu \mathrm{g} \mathrm{N} \mathrm{ml}^{-1}$ \\
\hline NO3mGLN & 0.003 & $\mathrm{~N}: \mathrm{C}$ (mass) \\
\hline NO3Pm & 0.01 & $\mathrm{~N}: \mathrm{C}$ (mass) \\
\hline NO3Qmin & 5.6 & $\mathrm{~N}: \mathrm{C}$ (mass) \\
\hline NNiRhGLN & 0.01 & \\
\hline NNiRhNO3 & 0.01 & \\
\hline NNiRhs & 0.01 & \\
\hline NNiRkNO3 & $3.5 \times 10^{-5}$ & $\mathrm{~N}: \mathrm{C}$ (mass) \\
\hline Qmax & 0.2 & $\mathrm{~N}: \mathrm{C}$ (mass) \\
\hline Qo & 0.08 & $\mathrm{~N}: \mathrm{C}$ (mass) \\
\hline Redco & 2.28 & $\mathrm{~N}: \mathrm{C}$ (mass) \\
\hline Umax & 0.05 & $\mathrm{C} \mathrm{C}^{-1} \mathrm{~h}^{-1}$ \\
\hline Ccellmax & 75 & pg C cell ${ }^{-1}$ \\
\hline Ccellmin & 35 & pg C cell ${ }^{-1}$ \\
\hline $\mathrm{SiKg}$ & 2 & $\mu \mathrm{mol} \mathrm{L} \mathrm{L}^{-1}$ \\
\hline Sicellmax & 40 & pg Si cell ${ }^{-1}$ \\
\hline Sicellmin & 7 & pg Si cell ${ }^{-1}$ \\
\hline$\mu \max$ & 2 & per day \\
\hline
\end{tabular}

$\mathrm{HCO}_{3}^{-}$to $\mathrm{CO}_{2}$ by extracellular carbonic anhydrase (Milligan and Morel 2002).

Another answer to the paradox of diatom success would be for silicon limitation itself to be advantageous. The increase in sinking rate that accompanies silicon limitation in diatoms has been proposed as a mechanism to transport di- atoms quickly to deeper, cooler, more nutrient-rich waters where their chances of long-term survival and eventual upwelling back up into favorable conditions are greater (Smetacek 1985). It has also been suggested that diatoms are better able to recover from silicon limitation than nitrogen limitation (Brzezinski and Nelson 1996), and it is here perhaps that the answer lies.

When faced with a shortfall of silicon, diatoms are known to arrest in the G2 phase of the cell cycle, which lies immediately prior to cell division and cell wall synthesis (Sullivan 1976; Vaulot et al. 1987; Brzezinski et al. 1990) and is the phase to which the uptake of silicon is largely confined (Sullivan and Volcani 1981; Hildebrand 2000). Such siliconstarved diatoms contain increased amounts of carbon, nitrogen, chlorophyll, and phosphorus (Harrison et al. 1977), in part because there is an increased number of biprotoplasmic cells poised to divide once their silicon quota has been filled. As a result, diatoms subjected to short-term silicon starvation are in reasonably sound physiological shape and may divide almost immediately after reintroduction of silicon to the growth medium (Sullivan 1976; Vaulot et al. 1987).

Such is not the case, however, for nitrogen-starved cells. Nitrogen-starved cells, in addition to containing low levels of nitrogen, contain lower than normal levels of carbon and chlorophyll (Harrison et al. 1977) and proteins and amino acids (Dortch 1982). Increased C/N ratios and lower cellular contents of nitrogen, protein, and chlorophyll are also seen in nitrogen-starved cells of nondiatom species (e.g., Sakshaug and Holm-Hansen 1977; Harrison et al. 1990). Nitrogen-starved cells are not poised to divide and should display a longer lag between the resupply of nutrients and cell division than would be seen with silicon starvation.

To demonstrate the potential advantage of silicon limitation, we have investigated the recovery of diatoms from both nitrate and silicon starvation in batch culture. These results have been used to verify the results of a coupled model of silicon and nitrogen metabolism in diatoms (Flynn et al. 1997; Flynn and Martin-Jézéquel 2000). We have then used the model to suggest that silicon limitation may be advantageous over nitrogen limitation to phytoplankton in areas of episodic nutrient input.

\section{Materials and methods}

Culture experiments-Exponential phase cultures of the marine diatom, Thalassiosira weissflogii (CCMP 1053) were

Table 2. Starting conditions for model runs to create Si-starved and N-starved populations.

\begin{tabular}{|c|c|c|c|c|}
\hline & Si starved & $\mathrm{N}$ starved & Unit & Definition \\
\hline $\mathrm{C}$ & 0.00897 & 0.00897 & $\mu \mathrm{g} \mathrm{C} \mathrm{ml}^{-1}$ & Algal C \\
\hline GLNP & 0.0009 & 0.0009 & $\mathrm{~N}: \mathrm{C}$ & Internal glutamine pool \\
\hline NO3 & 50 & 3.6 & $\mu \mathrm{mol} \mathrm{L}-1$ & Nitrate in medium \\
\hline NO3P & 0.0036 & 0.0036 & $\mathrm{~N}: \mathrm{C}$ & Internal nitrate pool \\
\hline NNiR & 0.0076 & 0.0076 & $\mathrm{~N}: \mathrm{C}\left(\mathrm{h}^{-1}\right)$ & Nitrate reductase activity \\
\hline Q & 0.154 & 0.154 & $\mathrm{~N}: \mathrm{C}$ & Cellular $\mathrm{N}: \mathrm{C}$ mass ratio \\
\hline Ccell & 50 & 50 & pg C cell ${ }^{-1}$ & $\mathrm{C}$ per cell \\
\hline ExtSi & 5 & 40 & $\mu \mathrm{mol} \mathrm{L}-1$ & Silicic acid in medium \\
\hline Cells ml $\mathrm{m}^{-1}$ & 179.4 & 179.4 & cells $\mathrm{ml}^{-1}$ & Cells per ml at $T_{0}$ \\
\hline Sicell & 14 & 14 & pg Si cell ${ }^{-1}$ & Si per cell \\
\hline
\end{tabular}



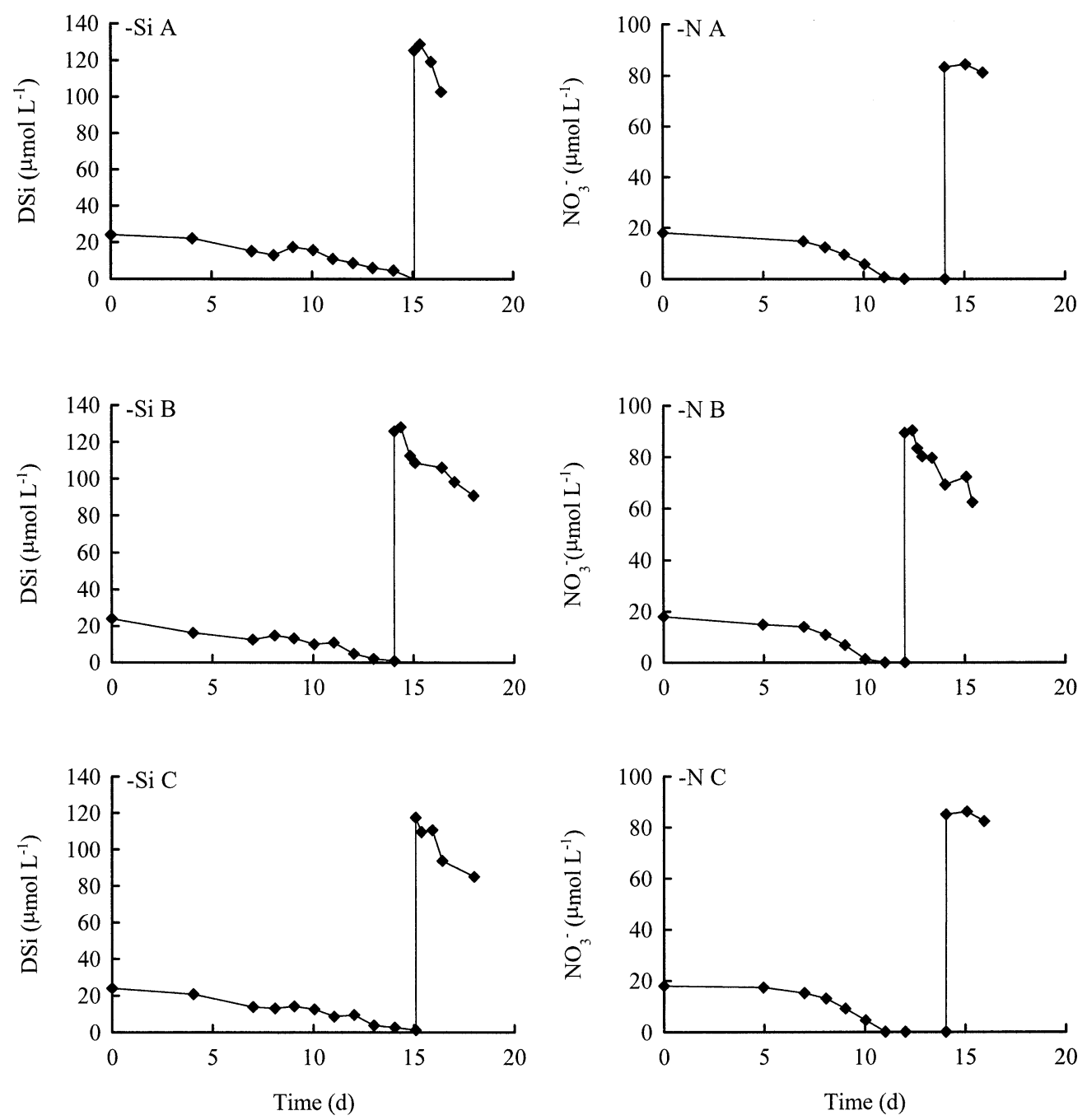

Fig. 1. Concentrations of silicic acid in the silicon-starved cultures (-Si A, - $\mathrm{Si} \mathrm{B},-\mathrm{Si} \mathrm{C}$ ) and concentrations of nitrate in the nitrogen-starved cultures $(-\mathrm{N} \mathrm{A},-\mathrm{N} \mathrm{B},-\mathrm{N} \mathrm{C})$.

inoculated to a density of a few hundred cells per milliliter into acid-rinsed and sterilized polycarbonate flasks containing either N-limited or Si-limited growth media made from 0.2$\mu \mathrm{m}$-filtered and autoclaved seawater from the North Sea. The seawater contained roughly $6 \mu \mathrm{mol} \mathrm{\textrm {L } ^ { - 1 }}$ dissolved silicon and $25 \mu \mathrm{mol} \mathrm{L} \mathrm{L}^{-1}$ nitrate, to which were added $12.5 \mu \mathrm{mol} \mathrm{\textrm {L } ^ { - 1 }}$ phosphate and trace metals and nutrients in $F / 2$ proportion with $\mathrm{P}$ addition. To Si-limited media, an additional $20 \mu \mathrm{mol}$ $\mathrm{L}^{-1} \mathrm{Si}$ and $200 \mu \mathrm{mol} \mathrm{L}{ }^{-1}$ nitrate were added. To N-limited medium, $100 \mu \mathrm{mol} \mathrm{L}{ }^{-1}$ Si but no nitrate was added.

Three replicate cultures per treatment (silicon or nitrate limited) were grown at $13^{\circ} \mathrm{C}$ on a $16: 8$ light: dark cycle (LD) and a photon flux of $50 \mu \mathrm{mol}$ photons $\mathrm{m}^{-2} \mathrm{~s}^{-1}$. Cell densities were monitored throughout the experiment using a Coulter Counter (Multisizer 2). Dissolved silicon and dissolved nitrate were determined manually via standard colorimetric analyses (Strickland and Parsons 1972).

Cells were grown until cell numbers stopped increasing. After $24 \mathrm{~h}$ of stationary phase, $100 \mu \mathrm{mol} \mathrm{L}{ }^{-1}$ nitrate or silicon was added to nitrogen- and silicon-starved cultures. Recovery from starvation was monitored via cell counts.
Modeling-The simple model for silicon-limited growth presented by Flynn and Martin-Jézéquel (2000) was merged with a model of ammonium and nitrate assimilation in phytoplankton (ANIM; Flynn et al. 1997) and used to simulate the growth of diatoms under varying conditions of silicic acid and nitrate. In this coupled model of silicon- and nitrogen-limited growth, maximal growth rates do not occur unless the cells acquire silicon and nitrogen at sufficient rates (Flynn and Martin-Jézéquel 2000). Cell division may be limited by the rate of silicon uptake. Silicon uptake, in turn, may be halted by the cessation of carbon accumulation that results from the deficiency of nitrogen.

There are a large number of constants associated with the model, most of them involved in the uptake and cellular processing of nitrogen. The values presented in Flynn et al. (1997) and Flynn and Martin-Jézéquel (2000) have been adopted for use here, with minor exception (Table 1). The minimum value for cellular N/C ratios $\left(Q_{0}\right)$, e.g., has been raised from $0.05 \mathrm{~g} \mathrm{~N} / \mathrm{g} \mathrm{C}$ to 0.08 , which cuts down the number of divisions carried out by the cells after external concentrations of nitrate drop to zero. There do not appear 
Table 3. Starting conditions for model run with nitrogen-starved and silicon-starved populations. Elemental ratios are expressed as ratios of mass, not as ratios of moles.

\begin{tabular}{|c|c|c|c|c|}
\hline & Si starved & $\mathrm{N}$ starved & Unit & Definition \\
\hline $\mathrm{C}$ & 0.00343 & 0.00178 & $\mu \mathrm{g} \mathrm{C} \mathrm{ml}^{-1}$ & Algal C \\
\hline GLNP & 3.57 & $1.5 \times 10^{-13}$ & $\mathrm{~N}: \mathrm{C}$ & Internal glutamine pool \\
\hline NO3 & 50 & 50 & $\mu \mathrm{mol} \mathrm{L}-1$ & Nitrate in medium \\
\hline NO3P & 0 & $6.8 \times 10^{-17}$ & $\mathrm{~N}: \mathrm{C}$ & Internal nitrate pool \\
\hline NNiR & 0.0074 & $1.5 \times 10^{-5}$ & $\mathrm{~N}: \mathrm{C}\left(\mathrm{h}^{-1}\right)$ & Nitrate reductase activity \\
\hline $\mathrm{Q}$ & 0.148 & 0.080024 & $\mathrm{~N}: \mathrm{C}$ & Cellular $\mathrm{N}: \mathrm{C}$ mass ratio \\
\hline Ccell & 68.5 & 35.5 & pg C cell ${ }^{-1}$ & $\mathrm{C}$ per cell \\
\hline ExtSi & 30 & 30 & $\mu \mathrm{mol} \mathrm{L}-1$ & Silicic acid in medium \\
\hline Cells ml ${ }^{-1}$ & 500 & 500 & cells $\mathrm{ml}^{-1}$ & Cells per $\mathrm{ml}$ at $T_{0}$ \\
\hline Sicell & 7.5 & 16.4 & pg $\mathrm{Si}$ cell ${ }^{-1}$ & Si per cell \\
\hline
\end{tabular}

to be any published estimates of this N/C mass ratio for nitrogen-starved $T$. weissflogii. The value of 0.08 used here corresponds to a molar $\mathrm{C} / \mathrm{N}$ ratio of 11 (vs. the 17 for 0.05 ), which is not far from the $\mathrm{C} / \mathrm{N}$ molar ratio of 9 reported for Fe-limited T. weissflogii (De La Rocha et al. 2000). The halfsaturation constant for silicon uptake $(\mathrm{SiKg})$ in the model was increased to $2 \mu \mathrm{mol} \mathrm{L}-1$ (from $0.345 \mu \mathrm{mol} \mathrm{L}^{-1}$ ) in light of the values of $2-4 \mu \mathrm{mol} \mathrm{L}{ }^{-1}$ that have been measured for silicon uptake by $T$. weissflogii in culture (Del Amo and Brzezinski 1999; De La Rocha et al. 2000).

Nutrient-starved diatoms were simulated from runs of the model in which either nitrate or dissolved silicon was utilized to exhaustion. The LD cycle used was 16:8 and starting conditions, detailed in Table 2, were the same in both treatments except for the concentrations of nitrate and silicon supplied. Addition of $40 \mu \mathrm{mol} \mathrm{L}{ }^{-1}$ dissolved silicon and 3.6

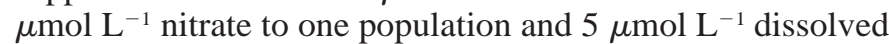
silicon and $50 \mu \mathrm{mol} \mathrm{L} \mathrm{L}^{-1}$ nitrate to the other ensured that one population ran into nitrogen starvation, while the other ran into silicon starvation. Cellular conditions at the 24th hour of stationary phase (Table 3 ), which occurred at model day

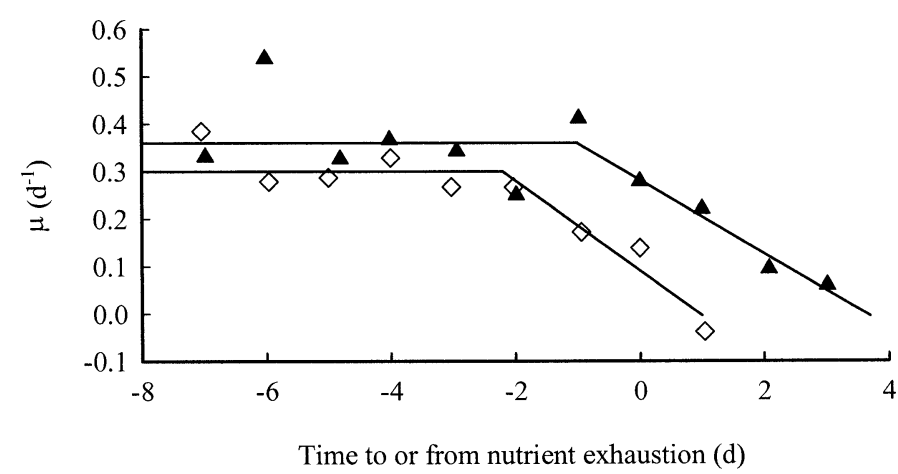

Fig. 2. Average growth rates versus the time before or after the depletion of the limiting nutrient for the nitrogen-starved (filled triangles) and silicon-starved (open diamonds) cultures. The horizontal lines shown represent the average growth rates during log phase of $0.37 \pm 0.09$ and $0.30 \pm 0.05 \mathrm{~d}^{-1}$ in the nitrogen- and siliconstarved cultures, respectively. The regression lines for the decline in growth rate with time shown are $y=-0.0934 x+0.0898\left(r^{2}=\right.$ 0.93 ) for the silicon-starved cultures and $y=-0.0776 x+0.2818$ $\left(r^{2}=0.97\right)$ for the nitrogen-starved cultures. The low value of $\mu$ at $t=-2$ and the high value at $t=-1$ in the nitrogen-starved cultures were not used in the calculation of the regression line.
8.86 for both scenarios, were used in a third model run where 500 cells per $\mathrm{ml}$ of each population were added to one batch of water and allowed to compete for the available nutrients.

\section{Results}

Induction of nitrogen and silicon starvation in culturesCultures in both nitrogen- and silicon-starved treatments initially ran out of the limiting nutrient between 11 and $15 \mathrm{~d}$ after inoculation. The removal of nitrate proceeded more rapidly than the removal of silicic acid (Fig. 1). Nitrate concentrations reached zero on the 11th day following inoculation in the nitrogen-starved cultures while silicic acid concentrations fell to zero on the 14th to 15th day in the silicon-starved treatments.

Growth rates in the cultures were the same ( $t$-test; $P=0.07$ ) at relatively high nutrient concentrations (above $\sim 10 \mu \mathrm{mol}$ $\mathrm{L}^{-1}$ ), averaging $0.30 \pm 0.05 \mathrm{~d}^{-1}$ in the silicon-starved treatments and $0.37 \pm 0.09 \mathrm{~d}^{-1}$ in the nitrogen-starved treatments (Fig. 2). There was a difference in the decline of growth rates at low nutrient concentrations between the two culturing conditions. Growth rates in the silicon-starved treatment began to drop $2 \mathrm{~d}$ before silicic acid concentrations were depleted from the culture medium. By comparison, however, growth rates in the nitrogen-starved treatment did not begin to decline until nitrate concentrations were exhausted (Fig. 2). In both sets of treatments, the decline in growth rate was linear over time (Fig. 2 ) and proceeded at rates that were indistinguishable from each other ( $t$-test; $P=0.2$ ).

The increase in cell numbers stopped abruptly in the silicon-starved cultures on about day 14 (Fig. 3), about the same time that silicic acid concentrations fell to zero (Fig. 1). In the nitrogen-starved cultures, the increase in cell numbers began leveling off on day 12 , but cell numbers did not stop increasing until day $13,2 \mathrm{~d}$ after the exhaustion of nitrate from the growth media (Figs. 1, 3).

Recovery from nitrogen and silicon starvation in cultures-After nutrient addition, cell numbers in siliconstarved cultures of $T$. weissflogii began to increase sooner than they did in the nitrogen-starved cultures (Figs. 3-5; $t$-test, $P=0.01$ ). Eight hours after the addition of nitrate or dissolved silicon, cell counts had increased by $14 \pm 5 \%$ in 

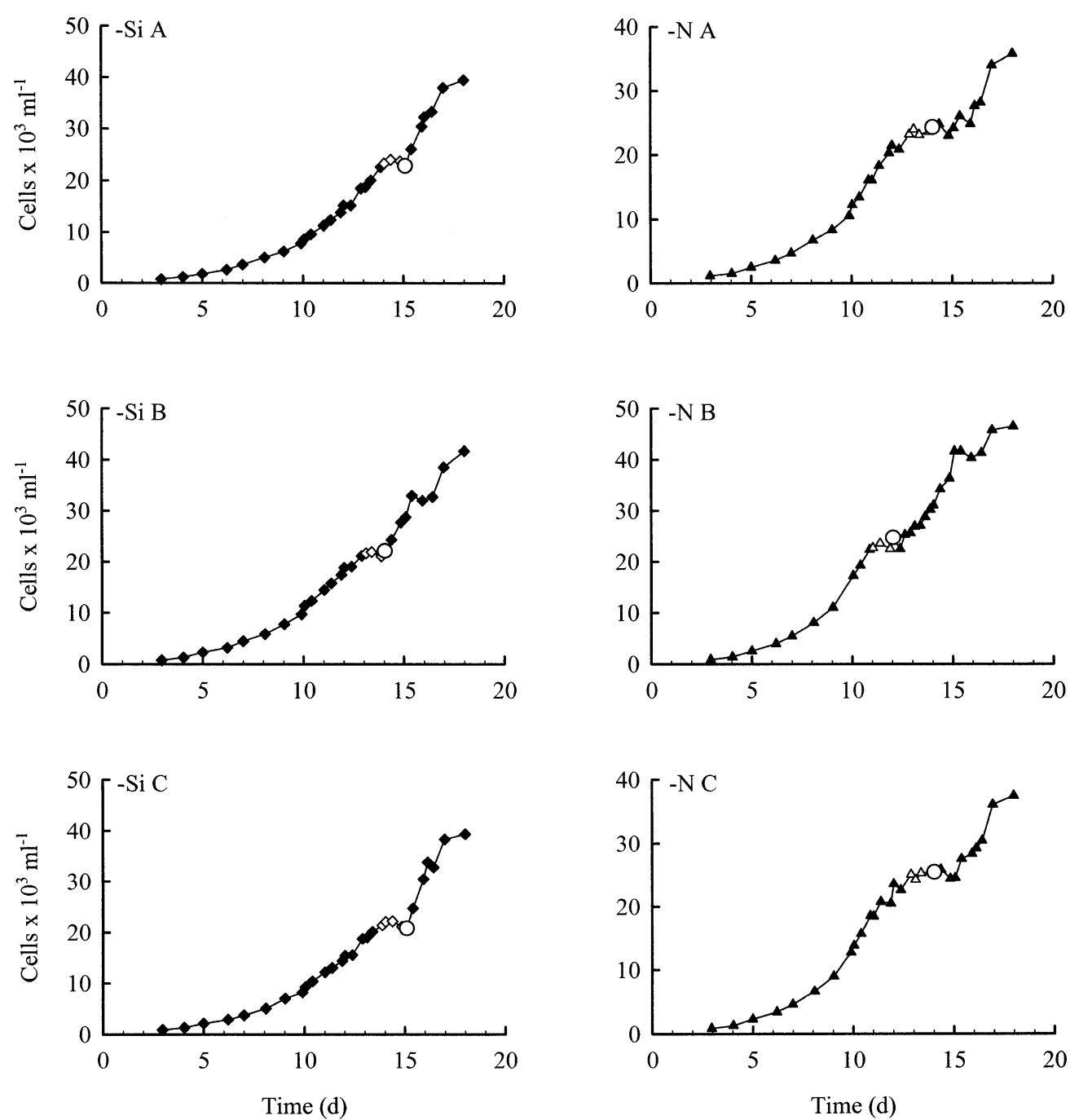

Fig. 3. Cells $\mathrm{ml}^{-1}$ over the course of the experiment for the three Si-starved cultures (-Si A, $-\mathrm{Si} \mathrm{B},-\mathrm{Si} \mathrm{C})$ and the three $\mathrm{N}$-starved cultures (-N A, -N B, -N C). Open symbols indicate the $24 \mathrm{~h}$ of stationary phase prior to the reintroduction of nutrients denoted by the open circles.

the silicon-starved cultures and decreased by $2 \pm 6 \%$ in the nitrogen-starved cultures. Growth rates in the first $24 \mathrm{~h}$ after nutrient readdition were higher in silicon-starved cells than in nitrogen-starved cells ( $t$-test; $P=0.008$ ). Silicon-starved cells displayed an average growth rate of $0.4 \pm 0.11 \mathrm{~d}^{-1}$ over the first $24 \mathrm{~h}$ after nutrient addition, whereas the growth rate over this period was $0 \pm 0.05 \mathrm{~d}^{-1}$ in the nitrogen-starved cultures and only $0.1 \pm 0.01 \mathrm{~d}^{-1}$ in the second $24 \mathrm{~h}$ after nutrient addition (Fig. 5). Cell numbers only began to significantly increase in the nitrogen-starved cultures $37 \mathrm{~h}$ after nutrient addition (Fig. 4).

Induction of nitrogen and silicon starvation in model runs-After $24 \mathrm{~h}$ in stationary phase, nitrogen-starved cells produced by the model contained less carbon, less nitrogen, and lower $\mathrm{N}: \mathrm{C}$ ratios $(Q)$ but higher levels of silicon than silicon-starved cells (Figs. 6, 7; Table 3). In addition, nitrogen-starved cells possessed smaller internal glutamine pools (GLNP) and lower levels of nitrate reductase (NNiR) activity (Table 3). The internal nitrate pools (NO3P) of both silicon- starved and nitrogen-starved cells were at or near zero at 24 $\mathrm{h}$ from the induction of stationary phase (Table 3 ).

As was the case with the cultures, the amount of time between exhaustion of the supply of the limiting nutrient and the cessation of cell division in the diatom population in the model was different under nitrogen versus silicon starvation. In the silicon-starved simulation, cell division ceased completely within $7 \mathrm{~h}$ of dissolved silicon concentrations dropping to zero (Fig. 6). Cell numbers, however, nearly doubled in the $24 \mathrm{~h}$ following exhaustion of nitrate in the simulation of nitrogen starvation (Fig. 7). Cell division, in fact, never fully ceased under nitrogen starvation, so the onset of stationary phase was taken to be the time when cell numbers ceased to increase by more than $1 \%$ over $24 \mathrm{~h}$, which occurred 2 model days after the depletion of nitrate.

Recovery from nitrogen and silicon starvation in model runs-In the model, cells that had been in stationary phase for $24 \mathrm{~h}$ due to nitrogen starvation had very low cellular contents of $\mathrm{N}\left(\mathrm{N}\right.$ cell $^{-1}$ in Fig. 7) and low $\mathrm{N}: \mathrm{C}$ ratios ( $Q$ in Fig. 7$) . \mathrm{N}$ 

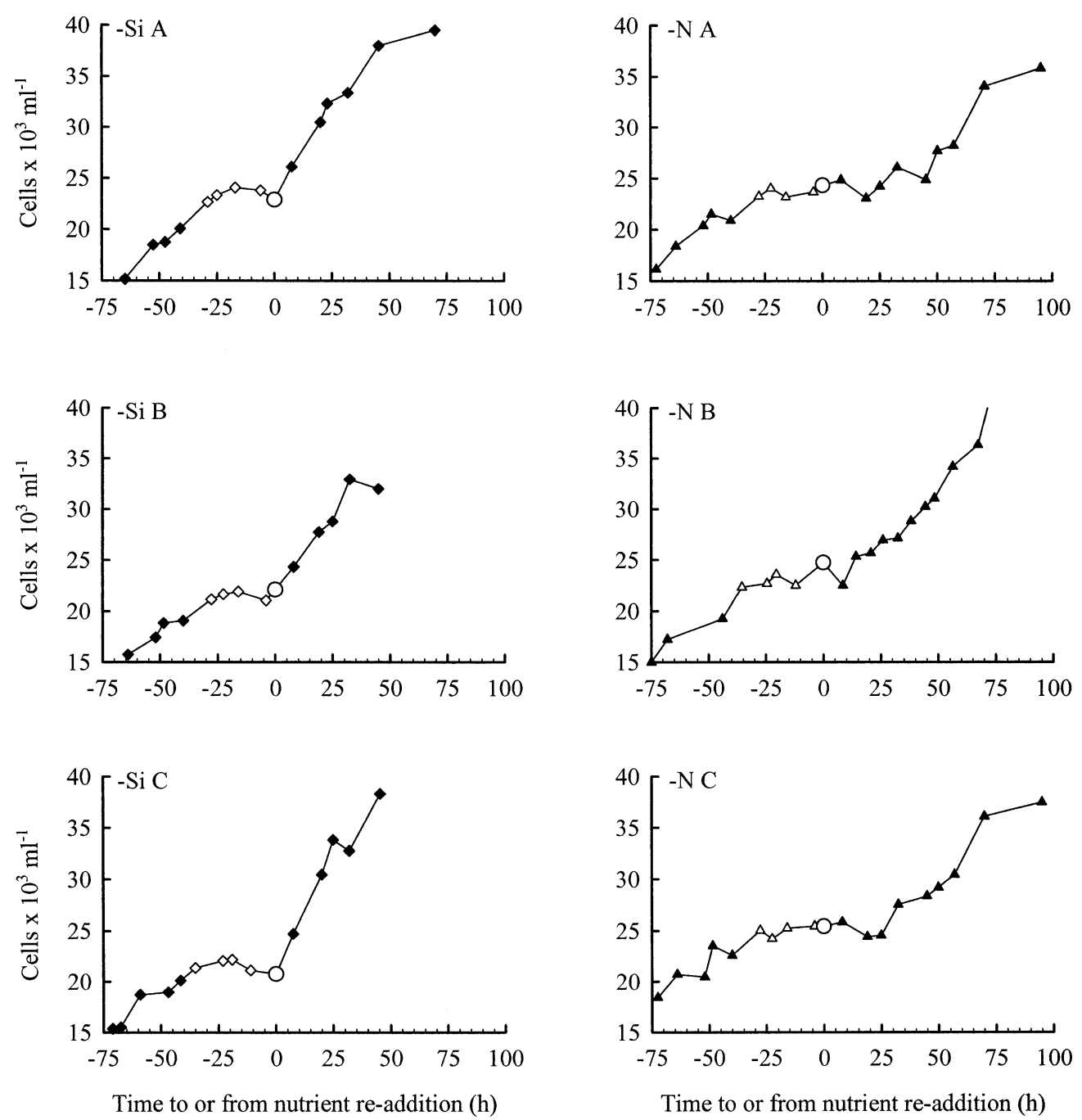

Fig. 4. Expanded view of the cell numbers in the $75 \mathrm{~h}$ prior to and $100 \mathrm{~h}$ following nutrient readdition for the $\mathrm{Si}$-starved (-Si A, -Si B, and -Si C) and N-starved (-N A, -N B, and -N C) treatments. Open symbols are as in Fig. 3.

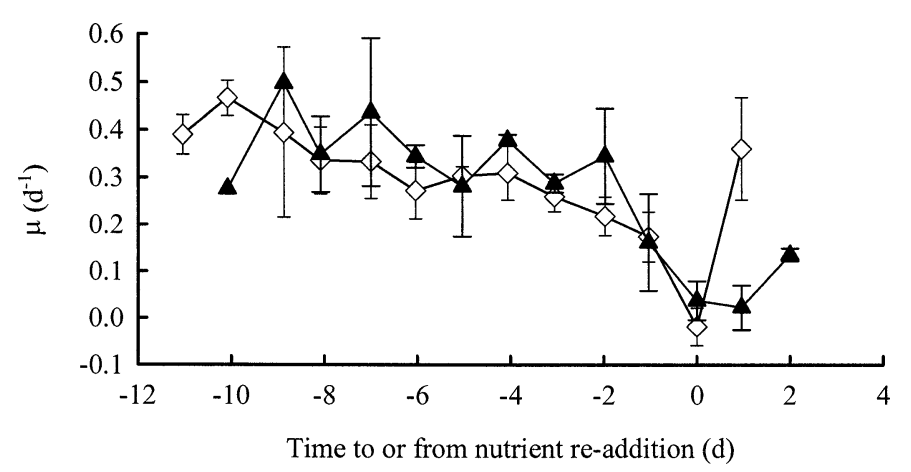

Fig. 5. Average growth rates (tabulated for 24-h intervals) over the experiment for the $-\mathrm{Si}$ (open diamonds) and $-\mathrm{N}$ (filled triangles) cultures. Error bars are the standard deviations of three replicate cultures. cell $^{-1}$ and $Q$ did not recover to the levels exhibited in the model by both nutrient-replete and silicon-starved cells until about 24 $\mathrm{h}$ after the cells had been introduced into high-nutrient conditions (Fig. 8). At low values of $Q$, cells are prohibited from dividing. The silicon-starved cells in the model were thus able to divide sooner than the nitrogen-starved cells. As a result, after several days, the population of cells springing from those that were silicon starved was significantly larger than the population descended from nitrogen-starved cells (Fig. 8). By the time the nutrients were once again exhausted, there were three times more descendants of the silicon starved than there were of the nitrogen starved.

\section{Discussion}

In both the cultures and in the model runs, cells that had been subjected to $24 \mathrm{~h}$ in stationary phase under silicon starvation resumed growth more quickly than those halted by nitrogen starvation (Figs. 3, 4, 5, 8). At first glance, several 

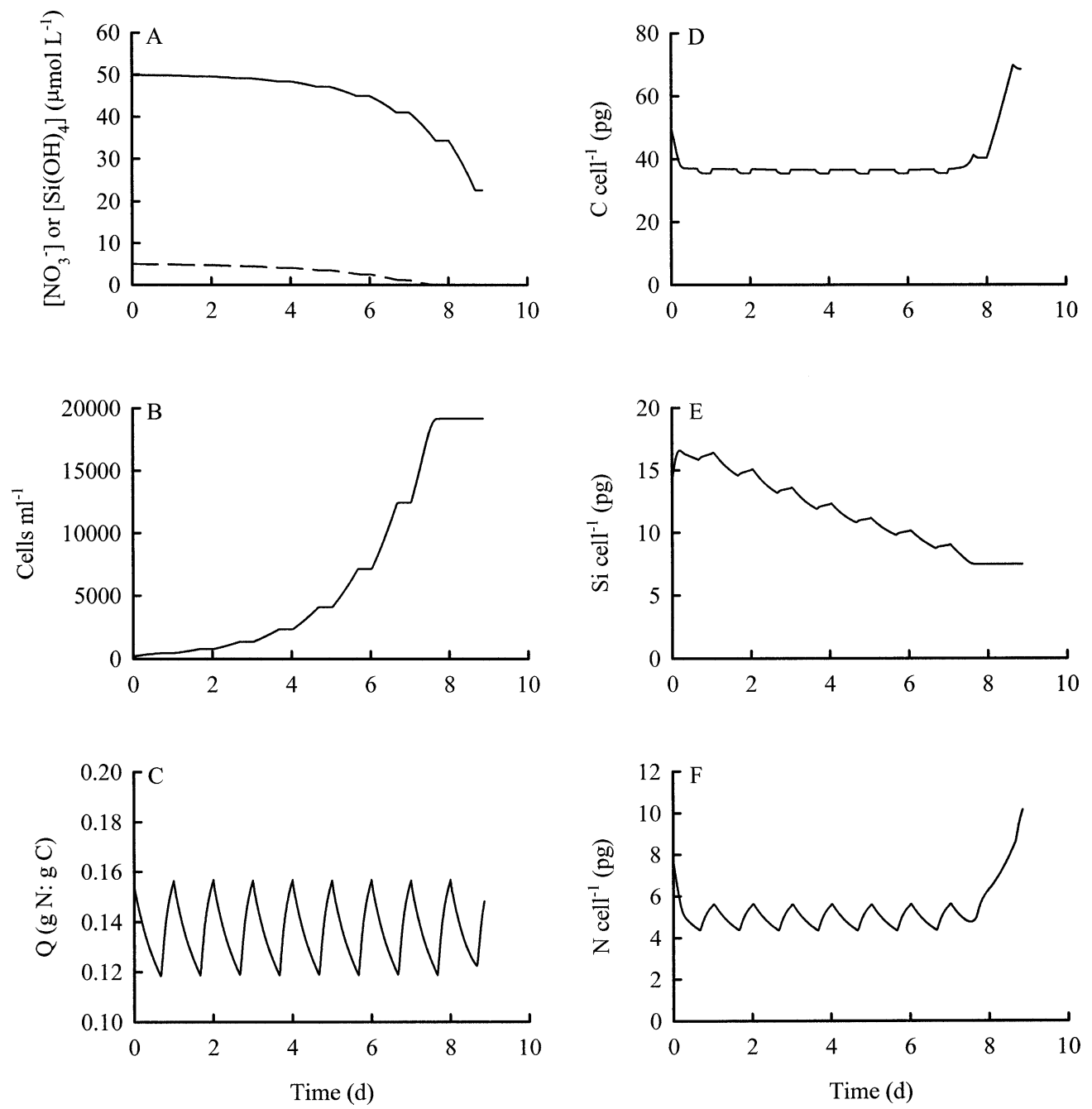

Fig. 6. Development of the silicon-starved population from the run of the model. (A) Concentrations of nitrate (solid line) and dissolved silicon (dashed line), (B) cells $\mathrm{ml}^{-1}$, (C) $Q$, the cellular $\mathrm{N}: \mathrm{C}$ mass ratio, (D) $\mathrm{C}_{\text {cell }}^{-1}$, (E) $\mathrm{Si}$ cell ${ }^{-1}$, (F) $\mathrm{N}_{\text {cell }}^{-1}$.

factors may contribute to this quicker recovery on the part of the silicon-starved cells: the better physiological condition of the silicon-starved cells, differences in the point of arrest in the cell cycle under silicon versus nitrogen starvation, and the longer time under conditions of nutrient exhaustion for $24 \mathrm{~h}$ of stationary phase for the nitrogen-starved cells. As we will show, the first two points are most likely the primary drivers of the relatively immediate onset of growth by the silicon-starved cells and of the lag time before growth in the nitrogen-starved cells, whereas the extra time spent under conditions of nutrient exhaustion does not appear to contribute much to the slower recovery of the nitrogen-starved cells following nutrient resupply.

Sliding into stationary phase-In both the model runs and in the cultures of $T$. weissflogii, cells faced with the exhaustion of dissolved silicon from the growth medium immediately ceased dividing (Figs. 2, 6). At this point, nitrate and dissolved phosphorus were still in adequate supply and so the cellular levels of carbon, nitrogen, and phosphorus in these cells should have been at least normal and may have been high (e.g., Harrison et al. 1977 and Fig. 6). Contributing to the normal to high levels of critical cellular constituents are the two points in the cell cycle at which siliconstarved cells arrest, the boundary between G1 and S (just before DNA synthesis) and in G2, immediately prior to mitosis and cell division (Vaulot et al. 1987; Brzezinski et al. 1990). At the end of G2, the cells will be essentially biprotoplasmic, as they are set to divide as soon as supplies of silicon adequate for the synthesis of new cell wall have been acquired. Arrest of some of the silicon-starved cells at the end of G1, due to a silicon requirement for DNA synthesis in diatoms (Darley and Volcani 1969), means that the cells have had time to acquire adequate supplies of nitrogen to complete the cell cycle (Vaulot et al. 1987) and generally increase in mass since the previous cell division.

In contrast, when nitrate was the nutrient completely taken up, cell division did not immediately cease (Figs. 2, 7). The cells that eventually reached stationary phase would have contained lower than normal levels of all constituents except 

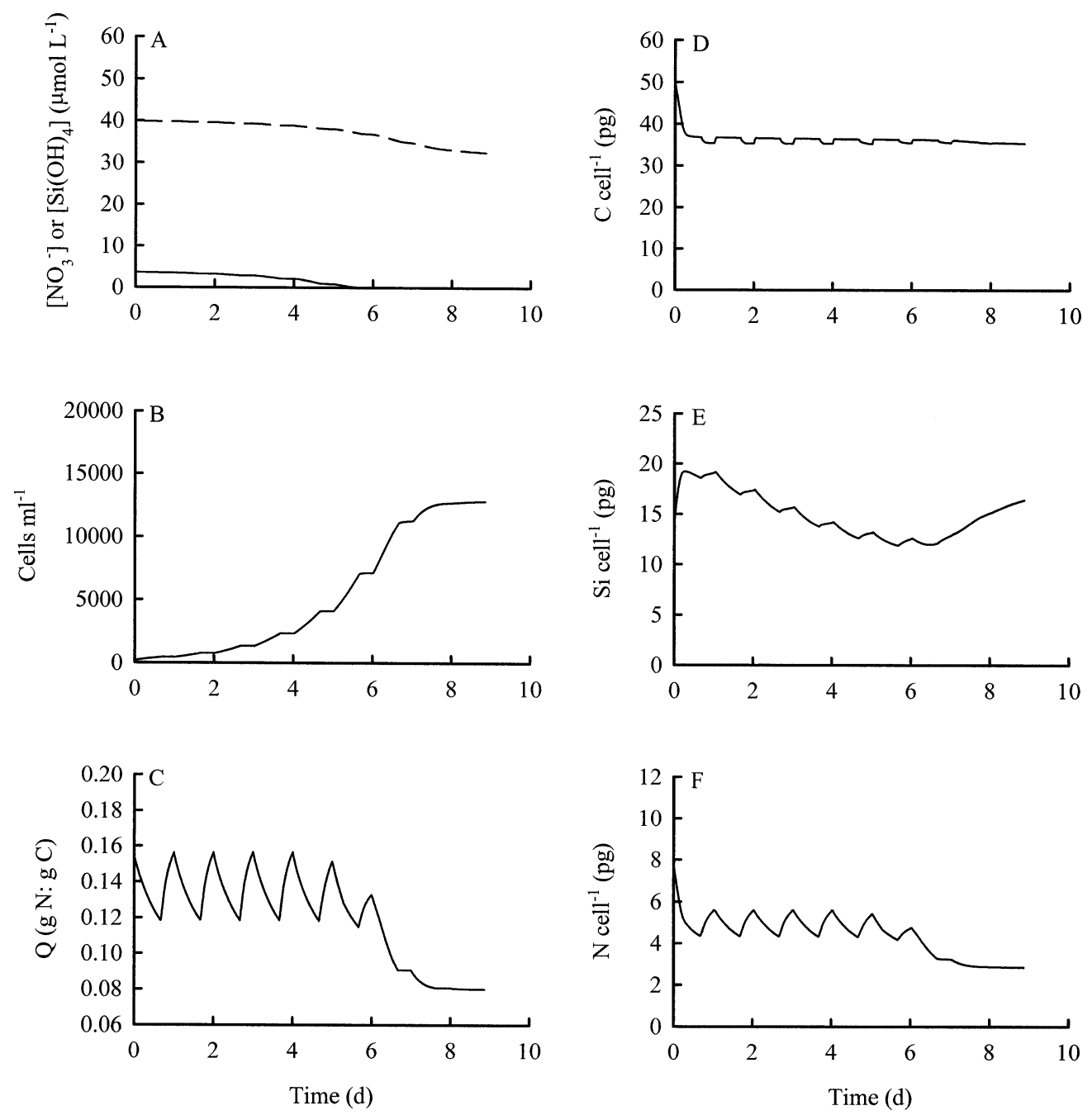

Fig. 7. Development of the nitrogen-starved population from the run of the model. (A) Concentrations of nitrate (solid line) and dissolved silicon (dashed line), (B) cells $\mathrm{ml}^{-1}$, (C) $Q$, the cellular $\mathrm{N}$ : C mass ratio, (D) $\mathrm{C}_{\text {cell }}^{-1}$, (E) $\mathrm{Si}$ cell ${ }^{-1}$, (F) $\mathrm{N}_{\text {cell }}^{-1}$.

for silicon (e.g., Harrison et al. 1977; Dortch 1982). In the cultures, growth rates in the nitrogen-starved treatment did not reach zero until nearly $4 \mathrm{~d}$ after the exhaustion of nitrate. Between nitrate depletion and the cessation of growth, cell numbers increased from $17 \times 10^{3}$ cells $\mathrm{ml}^{-1}$ to $25 \times 10^{3}$ cells $\mathrm{ml}^{-1}$ (Fig. 3), spreading the already limited nitrogen stores out among an additional $50 \%$ more cells. In the model, the continued growth of cells following nitrate depletion resulted in a halving of the nitrogen content of the cells (Fig. 7). When nitrogen-starved cells finally do stop growing, they arrest at various points in the midst of the G1 phase of the cell cycle (Vaulot et al. 1987), leaving them smaller and depleted in cellular constituents relative to silicon-starved cells.

Cessation of cell division in the Si-N model-Cell division in the coupled Si-N limitation model (Flynn et al. 1997; Flynn and Martin-Jézéquel 2000) is largely controlled by the cellular ratio of N/C. Provided that an accurate value for $Q_{0}$, the cellular N/C mass ratio below which cell division ceases, is used (which is a small challenge because there are few measurements of the elemental composition of nutrientstarved diatoms), the model results (Figs. 6, 7) match the culture results for T. weissflogii (Figs. 1, 3). Just as observed in culture, cell division in the model ceases immediately upon silicon depletion (Fig. 6). Cell numbers in the model increase by a further $78 \%$ following nitrate depletion (Fig. 7 ), versus the $50 \%$ observed in the culture. The similarity of the results of the experimental cultures and of the model runs lends support to the use of this model to explore nitrogen- and silicon-limited growth in diatoms.

As with the cultures, cell division in the model ceases gradually following the depletion of nitrate. By the second day following nitrate depletion, cell numbers increase by negligibly small amounts. This is a little shorter than the 3$4 \mathrm{~d}$ of growth following nitrate exhaustion observed in culture (Fig. 2). The span following nitrate depletion over which cells continued to divide could be extended by lowering the values of $U \max$, the amount of carbon fixed per amount of cellular carbon per hour. There is also a $50 \%$ 

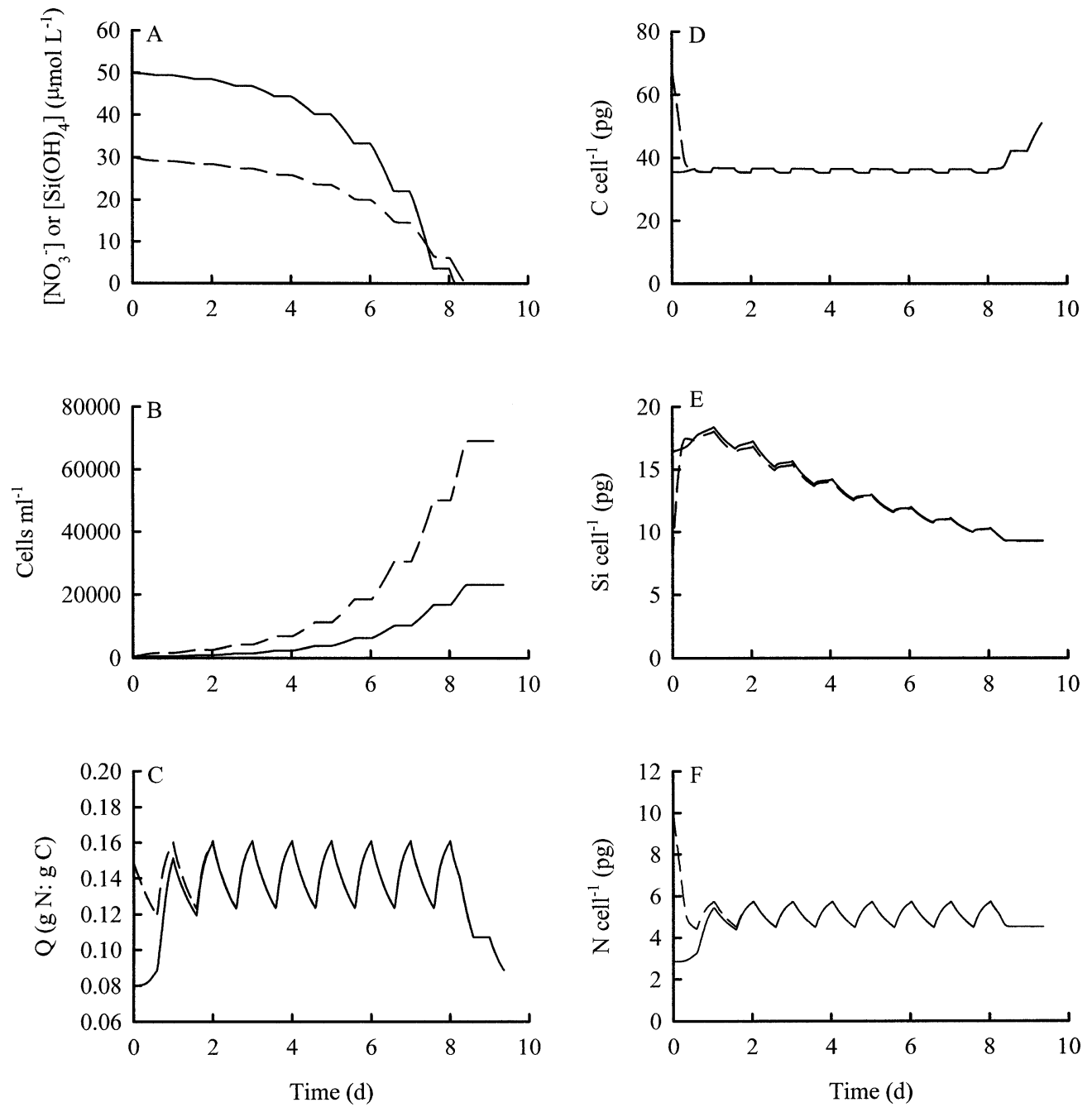

Fig. 8. Modeled recovery of diatoms from nitrogen and silicon starvation. The dashed line denotes cells that had been silicon starved and the solid line denotes cells that had been nitrogen starved except in panel A. (A) Concentrations of nitrate (solid line) and dissolved silicon (dashed line), (B) cells ml $\mathrm{ml}^{-1}$, (C) $Q$, the cellular $\mathrm{N}: \mathrm{C}$ mass ratio, (D) $\mathrm{C}_{\text {cell }}^{-1}$, (E) $\mathrm{Si}_{\text {cell }}^{-1}$, (F) $\mathrm{N}$ cell ${ }^{-1}$.

overshoot in the cell counts in the model, which could be remedied by further increasing the value of $Q_{0}$ over the 0.08 $\mathrm{g} \mathrm{N}: \mathrm{g}$ C used here.

Impact of points of cell cycle arrest on recovery-As noted previously, there are two points in the cell cycle where silicon-starved cells tend to arrest, at the end of G1 and, increasingly with the severity of silicon limitation, at the end of G2 (Vaulot et al. 1987; Brzezinski et al. 1990). By the end of G1, cells have acquired quantities of nitrogen adequate for the completion of the cell cycle (Vaulot et al. 1987). By the end of G2, the cell is ready to divide immediately upon the uptake of enough silicon to synthesize new frustules (Brzezinski et al. 1990). The lack of a time lag between silicon resupply and cell division reported here for both cultured and modeled diatoms has been seen previously, also for T. weissflogii, and ascribed to arrest of the silicon-limited cells at the end of G2 (Vaulot et al. 1987). In the same experiments, a lag before division of up to $16 \mathrm{~h}$ was observed, increasing with the degree of nitrogen starvation. Increasingly earlier arrest points within G1 with the severity of nitrogen deficiency, leading to progressively larger spans of time before DNA replication, could have been responsible for the expansion of the lag time before cell division (Vaulot et al. 1987).

The accumulation of resources in the descendants of the silicon starved - The faster recovery of silicon-starved diatoms when nutrients are resupplied gives them a head start of 30-50 h (e.g., Figs. 3, 4, 8) over a population of nitrogenstarved cells. If maximal growth rates are similar between the two groups, the number of cells descended from those that were nitrogen starved should never catch up to the number of cells arising from those that were silicon starved. For example, by the time the added nutrients in the final model run were consumed, silicon-starved cells had given rise to three times more cells than had the nitrogen-starved cells (Fig. 8). This translates into $75 \%$ of the supplied nitrogen 
and silicon being appropriated by the descendants of siliconstarved population to the detriment of the cells springing from those that were nitrogen starved.

Of course, while both silicon- and nitrogen-starved cells had been in stationary phase for $24 \mathrm{~h}$, they had experienced different durations of nutrient starvation due to the more abrupt halting of growth with nutrient depletion under silicon-deficient conditions. It may be asked whether, after 24 $\mathrm{h}$ of nutrient depletion (rather than $24 \mathrm{~h}$ of stationary phase), the silicon-starved cells still recover more quickly than the nitrogen-starved cells. To address this issue, an additional run of the model was carried out, this time comparing the Si-starved cells of Table 3 with cells that had been $\mathrm{N}$ starved in the model for only $24 \mathrm{~h}$.

Although the nitrogen-deficient cells had not yet entered the stationary phase of growth after $24 \mathrm{~h}$ of nitrogen starvation, they were already in poor condition. Levels of $\mathrm{C}$ per cell were $35.6 \mathrm{pg}$ versus the $68.5 \mathrm{pg}$ of the silicon-starved cells and $35.5 \mathrm{pg}$ of the nitrogen-starved cells after $24 \mathrm{~h}$ of stationary phase (Table 3). By this time, the internal glutamine pools of these cells were orders of magnitude lower than in the silicon-starved cells, and the nitrate reductase activity was depressed. Most critically for the growth of cells in the model, the cellular $\mathrm{N}: \mathrm{C}$ ratio $(Q$ on Table 3$)$ was down to 0.0906, which while higher than the rock bottom value of 0.0800 after $24 \mathrm{~h}$ of nitrogen-starved stationary phase, was significantly lower than the value of 0.148 in the silicon-starved cells. As a result, the cells starved of silicon for $24 \mathrm{~h}$ still vastly outgrew the cells that had been starved of nitrogen for the equivalent amount of time. In this case, $70 \%$ of the added nutrients wound up in the cells originating from those starved of silicon, not much of a difference from the $75 \%$ in the case of $24 \mathrm{~h}$ of stationary phase.

If the results from the bottle incubations and the model runs may be translated to coastal and upwelling zones, where nutrients are delivered in pulses, silicon starvation may help diatoms to respond more quickly to nutrient inputs than nonsiliceous phytoplankton, which largely face nitrogen rather than silicon limitation. The generally high growth rates of diatoms would amplify any head start over other phytoplankton yielded them by a quicker recovery from silicon starvation. If true, this would help to explain the dominant role of diatoms in the productivity of coastal and upwelling regions and the tendency for the bulk of their productivity to occur in blooms (Nelson et al. 1995). Competition between phytoplankton is, however, complex and growth rates are dependent on many factors, such as adaptation to new light and temperature levels. The type of nutrient starvation is here suggested as another factor that may be important to competition between different phytoplankton. Further experiments must be carried out to see whether or not the competitive advantage physiological state of silicon-starved diatom cells in culture over the short term carries over to the more complex situation of an upwelling zone with both siliceous and nonsiliceous phytoplankton over a slightly longer term.

\section{References}

BAnSE, K. 1995. Zooplankton: Pivotal role in the control of ocean production. ICES J. Mar. Sci. 52: 265-277.
Broecker, W. S., AND T.-H. Peng. 1982. Tracers in the Sea. Eldigio Press.

BRZEZINSKI, M. A. 1985. The Si:C:N ratio of marine diatoms: Interspecific variability and the effect of some environmental variables. J. Phycol. 21: 347-357.

—, AND D. M. Nelson. 1996. Chronic substrate limitation of silicic acid uptake rates in the western Sargasso Sea. Deep-Sea Res. II 43: 437-453.

- R. J Olson, And S. W. Chisholm. 1990. Silicon availability and cell-cycle progression in marine diatoms. Mar. Ecol. Prog. Ser. 67: 83-96.

Darley, W. M., And B. E. Volcani. 1969. Role of silicon in diatom metabolism. A silicon requirement for deoxyribonucleic acid synthesis in the diatom Cylindrotheca fusiformis Riemann and Lewin. Expl. Cell Res. 58: 334-342.

Davidson, A. T., D. Bramlich, H. J. Marchant, and A. MCMinN. 1994. Effects of UV-B irradiation on growth and survival of Antarctic marine diatoms. Mar. Biol. 119: 507-515.

Del Amo, Y., AND M. A. BRZEZINSKI. 1999. The chemical form of dissolved Si taken up by diatoms. J. Phycology 35: 1162-1170.

De La Rocha, C. L., D. A. Hutchins, M. A. Brzezinski, And Y. ZHANG. 2000. Effects of iron and zinc deficiency on elemental composition and silica production by diatoms. Mar. Ecol. Prog. Ser. 195: 71-79.

DORTCH, Q. 1982. Effect of growth conditions on accumulation on internal nitrate, ammonium, amino acids and protein in three marine diatoms. J. Exp. Mar. Biol. Ecol. 61: 243-264.

Dugdale, R. C., F. P. Wilkerson, and H. J. Minas. 1995. The role of a silicate pump in driving new production. Deep-Sea Res. I 42: 697-719.

Flynn, K. J., AND V. MARTin-JÉZÉQUel. 2000. Modelling Si-Nlimited growth of diatoms. J. Plankton Res. 22: 447-472.

- , M. J. R. FASHAM, AND C. R. HIPKIN. 1997. Modelling the interactions between ammonium and nitrate uptake in marine phytoplankton. Phil. Trans. R. Soc. Lond. B 352: 1624-1645.

Harrison, P. J., H. L. Conway, R. W. Holmes, and C. O. Davis. 1977. Marine diatoms grown in chemostats under silicate or ammonium limitation. III. Cellular chemical composition and morphology of Chaetoceros debilis, Skeletonema costatum, and Thalassiosira gravida. Mar. Biol. 43: 19-31.

- P. A. Thompson, AND G. A. CALDERwood. 1990. Effects of nutrient and light limitation on the biochemical composition of phytoplankton. J. Appl. Phycol. 2: 45-56.

HILDEBRAND, M. 2000. Silicic acid transport and its control during cell wall silicification in diatoms, p. 171-188. In E. Bauerlein [ed.], Biomineralization of nano- and micro-structures. Wiley$\mathrm{VCH}$.

Hutchins, D. A., AND K. W. BRUland. 1998. Iron-limited growth and $\mathrm{Si}: \mathrm{N}$ uptake ratios in a coastal upwelling regime. Nature 393: $561-564$.

Levasseur, M. E., AND J.-C. Therriault. 1987. Phytoplankton biomass and nutrient dynamics in a tidally induced upwelling: The role of the $\mathrm{NO}_{3}: \mathrm{SiO}_{4}$ ratio. Mar. Ecol. Prog. Ser. 39: 87-97.

Milligan, A. J., AND F. M. M. Morel. 2002. A proton buffering role for silica in diatoms. Science 297: 1848-1850.

Nelson, D. M., AND Q. DORTCH. 1996. Silicic acid depletion and silicon limitation in the plume of the Mississippi River: Evidence from kinetic studies in spring and summer. Mar. Ecol. Prog. Ser. 136: 163-178.

, P. Tréguer, M. A. Brzezinski, A. Leynaert, and B. Quéguiner. 1995. Production and dissolution of biogenic silica in the ocean: Revised global estimates, comparison with regional data, and relationship to biogenic sedimentation. Global Biogeochemical Cycles 9: 359-372.

RAVEN, J. A. 1983. The transport and function of silicon in plants. Biol. Rev. 58: 179-207. 
Sakshaug, E., And O. Holm-Hansen. 1977. Chemical composition of Skeletonema costatum (Grev.) Cleve and Pavlova (monochrysis) lutheri (Droop) as a function of nitrate-, phosphate-, and iron-limited growth. J. Exp. Mar. Biol. Ecol. 29: 1-34.

SMETACEK, V. S. 1985. Role of sinking in diatom life-history cycles: Ecological, evolutionary and geological significance. Mar. Biol. 84: 239-251.

Strickland, J. D. H., AND T. R. Parsons. 1972. A practical handbook of seawater analysis. Fisheries Research Board of Canada.

Sullivan, C. W. 1976. Diatom mineralization of silicic acid. I. $\mathrm{Si}(\mathrm{OH})_{4}$ transport characteristics in Navicula pelliculosa. J. Phycol. 12: 390-396.

, AND B. E. VolCANI. 1981. Silicon in the cellular metab- olism of diatoms, p. 15-42. In T. L. Simpson and B. E. Volcani [eds.], Silicon and siliceous structures in biological systems. Springer Verlag.

TAKEDA, S. 1998. Influence of iron availability on nutrient consumption ratio of diatoms in oceanic waters. Nature 393: 774 777.

Vaulot, D., R. J. Olson, S. Merke, and S. W. Chisholm. 1987. Cell-cycle response to nutrient starvation in two phytoplankton species, Thalassiosira weissflogii and Hymenomonas carterae. Mar. Biol. 95: 625-630.

Received: 9 January 2003

Accepted: 21 July 2003

Amended: 11 August 2003 